\title{
1 COVID-19 control across urban-rural gradients
}

4 Konstans Wells ${ }^{1, *}$, Miguel Lurgi ${ }^{1}$ Brendan Collins $^{2,3}$, Biagio Lucini ${ }^{4}$, Rowland R. Kao ${ }^{5}$, Alun L.

5 Lloyd $^{6}$, Simon D.W. Frost ${ }^{7}$, Mike B. Gravenor ${ }^{8}$

6

$7 \quad{ }^{1}$ Department of Biosciences, Swansea University, Swansea SA2 8PP, Wales, UK

$8{ }^{2}$ Department of Public Health and Policy, University of Liverpool, Liverpool L69 3GB, UK

$9 \quad{ }^{3}$ Health and Social Services Group, Welsh Government, UK

$10{ }^{4}$ Department of Mathematics, Swansea University, Swansea SA2 8PP, Wales, UK

$11{ }^{5}$ Royal (Dick) Veterinary School of Veterinary Studies, University of Edinburgh, Midlothian,

${ }^{6}$ Biomathematics Graduate Program and Department of Mathematics, North Carolina State

University, Raleigh, NC 27695, USA

${ }^{7}$ Microsoft Research Lab, Redmond, Washington, WA 98052, USA and London School of

Hygiene and Tropical Medicine, London, WC1E 7HT

${ }^{8}$ Swansea University Medical School, Swansea University, Swansea SA2 8PP, Wales, UK

* Corresponding author 
medRxiv preprint doi: https://doi.org/10.1101/2020.09.07.20189597; this version posted September 10, 2020. The copyright holder for this preprint (which was not certified by peer review) is the author/funder, who has granted medRxiv a license to display the preprint in It is made available under a CC-BY-NC-ND 4.0 International license .

COVID-19 disease landscapes

\section{Abstract}

28 Controlling the regional re-emergence of SARS-CoV-2 after its initial spread in everchanging personal contact networks and disease landscapes is a challenging task. In a landscape context, contact opportunities within and between populations are changing rapidly as lockdown measures are relaxed and a number of social activities re-activated. Using an individual-based metapopulation model, we explored the efficacy of different control strategies across an urban-rural gradient in Wales, UK. Our model shows that isolation of symptomatic cases, or regional lockdowns in response to local outbreaks, have limited efficacy unless the overall transmission rate is kept persistently low. Additional isolation of non-symptomatic infected individuals, who may be detected by effective test and trace strategies, is pivotal to reduce the overall epidemic size over a wider range of transmission scenarios. We define an 'urban-rural gradient in epidemic size' as a correlation between regional epidemic size and connectivity within the region, with more highly connected urban populations experiencing relatively larger outbreaks. For interventions focused on regional lockdowns, the strength of such gradients in epidemic size increased with higher travel frequencies, indicating a reduced efficacy of the control measure in the urban regions under these conditions. When both non-symptomatic and symptomatic individuals are isolated or regional lockdown strategies are enforced, we further found the strongest urban-rural epidemic gradients at high transmission rates. This effect was reversed for strategies targeted at symptomatics only. Our results emphasise the importance of test-and-tracing strategies and maintaining low transmission rates for efficiently controlling COVID19 spread, both at landscape scale and in urban areas. 
medRxiv preprint doi: https://doi.org/10.1101/2020.09.07.20189597; this version posted September $10,2020$. The copyright holder for this preprint (which was not certified by peer review) is the author/funder, who has granted medRxiv a license to display the preprint in It is made available under a CC-BY-NC-ND 4.0 International license .

COVID-19 disease landscapes

52

53

54

55

56

57

\section{Author summary}

The spread of infectious diseases is the outcome of contact patterns and involves source-sink dynamics of how infectious individuals spread the disease through pools of susceptible individuals. Control strategies that aim to reduce disease spread often need to accept ongoing transmission chains and therefore, may not work equally well in different scenarios of how individuals and populations are connected to each other. To understand the efficacy of different control strategies to contain the spread of COVID19 across gradients of urban and rural populations, we simulated a large range of different control strategies in response to regional COVID19 outbreaks, involving regional lockdown and the isolation individuals that express symptoms and those that developed not symptoms but may contribute to disease transmission. Our results suggest that isolation of asymptomatic individuals through intensive test-and-tracing is important for efficiently reducing the epidemic size. Regional lockdowns and the isolation of symptomatic cases only are of limited efficacy for reducing the epidemic size, unless overall transmission rate is kept persistently low. Moreover, we found high overall transmission rates to result in relatively larger epidemics in urban than in rural communities for these control strategies, emphasising the importance of keeping transmission rates constantly low in addition to regional measures to avoid the disease spread at large scale. 
medRxiv preprint doi: https://doi.org/10.1101/2020.09.07.20189597; this version posted September $10,2020$. The copyright holder for this preprint (which was not certified by peer review) is the author/funder, who has granted medRxiv a license to display the preprint in It is made available under a CC-BY-NC-ND 4.0 International license .

COVID-19 disease landscapes

78

79

80

81

82

\section{Introduction}

In the absence of a vaccine against COVID-19 during the initial pandemic phase,

stakeholders are confronted with challenging decision-making to balance constraints of social interaction and the efficient isolation of infectious individuals with economic and social pressures. There is now growing scientific evidence of how different containment strategies compare to each other amid the challenges of asymptomatic disease transmission and the ongoing need for improved estimates of epidemiological key parameters [1, 2]. Nonpharmaceutical interventions for curbing the spread of COVID-19 rely on the isolation of infectious individuals or general social distancing policies to reduce interactions between undetected infectious individuals and those susceptible to the disease. During uncontrolled pandemic spread, a central aim is to reduce case incidence in order to release the pressure on health systems. A more fundamental, long-term, goal should be to reduce the overall epidemic size and allow particularly those most prone to suffer from the disease to escape infection until a pharmaceutical measure such as a vaccine is in place.

Control strategies are likely to be regional, and temporal, aiming to reduce the timedependent reproduction number $R$, while accepting that ongoing transmission is long term. But how should these regional and temporary strategies account for disease spread in everchanging transmission landscapes? One particular question faced by many countries is how do different control strategies differ in their efficacy in preventing disease spread across urban-rural gradients of different population densities and connectivity in urban and rural landscapes?

The spread of infectious disease is rarely random. It is instead likely driven by the complex and heterogeneous social interaction patterns of humans and the stark gradient between urban 
medRxiv preprint doi: https://doi.org/10.1101/2020.09.07.20189597; this version posted September 10, 2020. The copyright holder for this preprint (which was not certified by peer review) is the author/funder, who has granted medRxiv a license to display the preprint in COVID-19 disease landscapes

103

104

105

106

107

108

109

110

111

112

113

114

115

116

117

119

120

and rural populations. In a landscape context, contact opportunities within and among populations across urban-rural gradients, and source-sink dynamics arising from infectious individuals encountering pools of susceptible individuals, are the ultimate drivers of disease spread. Disease spread is thus hampered if contact opportunities are lower in poorly mixed populations [3-5]. Heterogeneity in contact patters of individuals and among social groups is also assumed to impact the depletion of the pool of susceptible individuals and the build-up of possible herd immunity that prevent further spread [6, 7]. Hence, future short- and longterm mitigation strategies that focus on managing regional and erratic outbreaks would benefit from a better understanding of which control strategies provide the best possible outcome under variable regional conditions.

To the best of our knowledge, there is so far little evidence of how various disease control strategies differ in their efficacy across urban-rural gradients [8]. To address this gap, using an individual-based metapopulation model, we explore the outcomes of different control strategies to contain the epidemic size of COVID-19 in ever changing disease landscapes of case numbers and susceptible depletion, which involve strong urban-rural gradients.

Our modelling approach is strategic, in contrast to many tactical COVID-19 simulation models that have focused on replication of specific characteristics of real outbreaks with the aim of predicting the epidemic in specific locations $[1,9,10]$. Rather than modelling a certain scenario, we aim to define wide ranges and explore the model behaviour across a large array of combinations of transmission and control parameters. The influence of each parameter on particular outcomes can then be explored statistically. In this manner we aim to highlight how basic properties of realistic metapopulations' structure that include urban-rural gradients, can affect the impact of control measures. 
medRxiv preprint doi: https://doi.org/10.1101/2020.09.07.20189597; this version posted September 10, 2020. The copyright holder for this preprint (which was not certified by peer review) is the author/funder, who has granted medRxiv a license to display the preprint in It is made available under a CC-BY-NC-ND 4.0 International license .

COVID-19 disease landscapes

\section{Methods}

Case study of a rural-urban metapopulation in Wales

In order provide an empirical basis to explore possible COVID-19 spread across an urbanrural gradient and the efficacy of different disease control measures, we selected four counties in southwestern Wales (Pembrokeshire, Carmarthenshire, Swansea, Neath Port Talbot) with a total human population size of 701,995 (hereafter termed 'metapopulation') dispersed over an area of $4,811 \mathrm{~km}^{2}$ as a case study. This area was selected because of its strong urban-rural gradient, from city centres to sparsely occupied farming localities, and readily available demographic data.

We used demographic data from the United Kingdom 2011 census (Office for National Statistics, 2011, www.ons.gov.uk), and constructed a metapopulation model at the level of Lower Layer Super Output Area (LSOA), which provided $M=422$ geographical units of regional populations with a mean of 1,663 individuals $(\mathrm{SD}=387)$ each.

We used a gravity model to define the connections between populations, as it is capable of reflecting the connectivity underpinning landscape-scale epidemics $[11,12]$. In particular, a gravity model was chosen as the LSOA administrative units are characterized by fairly similar population sizes, although they can have widely areas and hence different population densities. We calculated for each pair of populations a gravity measure $T_{i, j}$ of the relative strength of how individuals are attracted to population $i$ from populations $j$ by accounting for local population sizes $N$ and weighted pairwise Euclidian distance measures $d^{\zeta}$, including the ten nearest populations $k$ of the attractive population: 
medRxiv preprint doi: https://doi.org/10.1101/2020.09.07.20189597; this version posted September 10, 2020. The copyright holder for this preprint (which was not certified by peer review) is the author/funder, who has granted medRxiv a license to display the preprint in It is made available under a CC-BY-NC-ND 4.0 International license .

COVID-19 disease landscapes

153

154

155

156

157

158

159

160

161

162

163

164

165

166

167

168

169

170

171

172

173

174

175

$$
T_{i, j}=\frac{\log \left(N_{i}+\sum_{k=1}^{10} \frac{N_{k}}{d_{i, k}^{\zeta}}\right) * \log \left(N_{j}\right)}{d_{i, k}^{\zeta}}
$$

We assumed this approach to reflect reasonably well situations in which people are most attracted to higher density population clusters of urban populations (i.e. Swansea in our case study; the arbitrary selected number of ten nearest populations generates larger values of $T_{i, j}$ if the attractant population is closely surrounded by others; Fig S1). The scaling factor $\zeta(0 \leq$ $\zeta \leq 1)$ is a sampled parameter that may vary across scenarios, accounting for the uncertainty in population connectivity. For each population $i$, we computed a regional gravity index (with self-terms of $T_{i, j}^{*}$ for $i=j$ being zero):

based on the scaled (mean subtracted from values divided by $1 \mathrm{SD}$ ) values of $T_{i, j}$ (denoted $T_{i, j}^{*}$, which we assumed to reflect the overall connectivity of the population within the global metapopulation. We used values of $T_{i, j}^{*}$ multiplied by the commuter travel frequency among populations $(\rho)$ to compute the number of individuals visiting each population from elsewhere.

Within each local patch in the metapopulation, individuals encounter each other depending on their social interactions. The daily within-population contact numbers $F_{i, t}$ for any individual $i$ at time $t$ is assumed to be a random draw given by the sum of contacts drawn from a negative binomial (with $r=3$ and $p=0.26$, resulting in contact numbers with mean of 9 and SD of 6) and lognormal distribution (with mean $=3$ and $\mathrm{SD}=2$, resulting in additional 
medRxiv preprint doi: https://doi.org/10.1101/2020.09.07.20189597; this version posted September 10, 2020. The copyright holder for this preprint (which was not certified by peer review) is the author/funder, who has granted medRxiv a license to display the preprint in It is made available under a CC-BY-NC-ND 4.0 International license .

COVID-19 disease landscapes

176

177

178

contact numbers with mean of 12 and SD of 16), whereby the lognormal distribution accounts for the 'long-tail' of contact frequency distributions. These parameters were based on a previous study of social contact frequencies in the UK [13]. For simplicity, and having in mind the main focus of this study on metapopulation-level patterns of disease spread, we did not account for repeated contact with the same individuals such as household or group members over different days. For simplicity, commuting individuals were assumed to return to their home populations in each time step, and their contacts were draw in the same way as for non-commuting individuals.

\section{Modelling the outcome of different disease control strategies in variable disease landscapes}

We ran numerical simulations of an individual-based stochastic difference equation S-E-A-IR model at daily time steps (see Supplementary materials), with individuals transitioning from a (S)usceptible compartment to being (E)xposed if infected. Exposed individuals become either infectious and symptomatic (I) or infectious but asymptomatic (A) after an incubation period of $\tau$ days. They then transition to a (R)emoved compartment with the recovery rate $\gamma$, which removes them from taking any further part in the transmission cycle.

Both symptomatic and asymptomatic individuals can expose those susceptible to the virus.

The force of infection $\lambda_{i, t}$, i.e. the probability that a susceptible individual $i$ acquires SARSCoV-2 at time $t$, is calculated by considering the probabilities of the virus being transmitted from any interacting infected individual $k$ (with $k \in 1 \ldots K_{i, t}$, and $K_{i, t}$ being the number of all infectious individuals in the randomly sampled daily contact number $F_{i, t}$ of individual $i$ ); $\lambda_{i, t}$ can be computed based on the probability that none of the contact events with an infectious individual leads to an infection: 
medRxiv preprint doi: https://doi.org/10.1101/2020.09.07.20189597; this version posted September $10,2020$. The copyright holder for this preprint (which was not certified by peer review) is the author/funder, who has granted medRxiv a license to display the preprint in It is made available under a CC-BY-NC-ND 4.0 International license .

COVID-19 disease landscapes

201

202

203

204

205

206

207

208

209

210

211

212

213

214

215

216

217

218

220

221

223

$$
\lambda_{i, t}=1-\prod_{k \in\left\{1 \ldots K_{i, t}\right\}}\left(1-\beta \omega_{k}\right)
$$

where $\beta$ is the disease transmission parameter, and $\omega_{k}$ is a scaling factor of infectiousness of asymptomatic relative to infectious individuals with $0<\lambda_{i, t}<1$.

To explore different scenarios of local and global epidemic sizes, we accounted for different pandemic stages and uncertainty in epidemiological parameters by varying systematically the following six parameters (see Supplementary Material, Table S1):

1) Transmission parameter $(\beta)$,

2) The proportion of individuals that remain asymptomatic after infection $(\varphi)$,

3) The relative infectiousness of asymptomatic disease carriers $(\omega)$,

4) Commuter travel frequency of individuals between populations $(\rho)$,

5) Density dependence of individual contact numbers $(\delta)$,

6) Proportion of the overall population resistant/ recovered from infection at the onset of simulations.

Density-dependence of contact numbers (a population-level attribute) was modelled by calculating the scaled regional population density (i.e. all values divided by maximum density) to the power of the parameter $\delta$ and multiplied the corresponding values with the lognormal ('long-tail') component of the daily contact numbers $F_{i, t}$. The resulting value corresponds to the same contact frequencies if $\delta$ approaches zero and truncated contact frequencies at low population densities if $\delta$ approaches one. Due to the lack of better empirical evidence, we assumed this approach to represent the situation in which an increase in population density (in urban areas) can result in a larger overall number of random 
medRxiv preprint doi: https://doi.org/10.1101/2020.09.07.20189597; this version posted September 10, 2020. The copyright holder for this preprint (which was not certified by peer review) is the author/funder, who has granted medRxiv a license to display the preprint in It is made available under a CC-BY-NC-ND 4.0 International license .

COVID-19 disease landscapes

226

227

228

229

231

232

233

235

236

237

239

240

241

242

244

245

246

247

encounters between citizens and higher contact frequencies between individuals of the same community in urban areas [14].

To assess and compare the efficacy of different, idealized, disease control strategies, we defined three general control strategies:

i) Trace and isolation of any infected individuals with a certain proportion $(\kappa)$ of all infected individuals successfully isolated (removal of individuals in disease states E, A, I, reflecting scenarios where intensive and continuous testing and/or intensive contact tracing would allow removal of any infected individuals; termed 'trace all' in figures).

ii) Trace and isolation of symptomatic individuals only with a certain proportion $(\varepsilon)$ of symptomatic individuals successfully isolated (removal of individuals in disease state I, reflecting scenarios where symptomatic cases isolate without any additional contract tracing or testing; termed 'trace symptomatic only' in figures).

iii) Regional temporary reduction of transmission rates ('regional lockdown') in response to a regional outbreak within the modelled LSOA administrative units, with four parameters to vary for decision making and control: (1) a threshold $\alpha$ defining the proportion of the regional population to be in disease state I, (2) lockdown stringency $\phi$ (the factor by which the transmission parameter is reduced), (3) travel ban distance $v$ (the maximum distance from which individuals are allowed to visit a locked-down population), and (4) duration of regional lockdown $(\eta)$. 
medRxiv preprint doi: https://doi.org/10.1101/2020.09.07.20189597; this version posted September 10, 2020. The copyright holder for this preprint (which was not certified by peer review) is the author/funder, who has granted medRxiv a license to display the preprint in It is made available under a CC-BY-NC-ND 4.0 International license .

COVID-19 disease landscapes

250 For simplicity, we did not account for possible individual heterogeneity in transition probabilities between different disease states but rather assumed constant 'average' transition probabilities in each scenario, albeit waiting times at different disease states are heterogeneous for many infectious diseases [15]. Similarly, we assume that the delay in the detection of individuals in different disease states is covered in the 'average' parameter of tracing/removing these individuals from transmission cycles as part of control strategies. We do so as here we are solely interested in population level outcomes of COVID19 spread in response to different control strategies.

Numerical simulations

To be able to assess the efficacy of these control strategies as compared to a reference, we defined 10,000 'baseline' transmission scenarios by varying the epidemiological parameters defining the spread scenarios (1-6 above). We performed independent numerical simulations for each parameter combination. We then combined each baseline transmission scenario with varying parameters for each of the three control strategies, running a total of 40,000 simulations, each for a time period of 100 days, which we assumed to be sufficiently long to capture the epidemic dynamics in response to different parameter values. Parameter values were sampled using latin hypercube sampling [16]; see Table S1 for ranges of parameter values used.

We started each simulation by randomly allocating $n=422$ individuals as infectious (corresponding to the number of populations, but not necessarily one infectious individual in each population and infectious individuals are not necessarily seeded in high density populations) in the metapopulation. While this seeding of the epidemic does not represent any particular 'true' epidemic state in the studied population, we have chosen this the seeding 
medRxiv preprint doi: https://doi.org/10.1101/2020.09.07.20189597; this version posted September $10,2020$. The copyright holder for this preprint (which was not certified by peer review) is the author/funder, who has granted medRxiv a license to display the preprint in It is made available under a CC-BY-NC-ND 4.0 International license .

COVID-19 disease landscapes

together with the varying number of initially resistant proportion of populations to enable us to explore different scenarios of dynamic disease landscapes rather than any particular past or current state.

\section{Output summary}

For each simulation, we computed the epidemic sizes as the numbers of individuals that had been symptomatic (we considered symptomatic cases only as asymptomatic cases are less likely to result in hospitalization or any other severe health burden) for each population and at the metapopulation scale (i.e. entire population). In order to explore the sensitivity of different control strategies to different epidemiological parameters, we calculated the relative differences in epidemic sizes ('relative epidemic size') for each disease control scenario and the corresponding baseline scenario at regional and metapopulation scale such that values close to zero mean effective control and larger values mean less effective control. Moreover, we computed for each baseline scenario the strength of correlation (expressed as the $r$ value from Spearman rank correlation) between the regional relative epidemic size and the respective regional gravity index ('urban-rural gradient in relative epidemic size') in order to explore whether control strategies varied in their efficacy across urban-rural gradients. A strong positive correlation can be interpreted as a strong urban-rural gradient of disease spread, with smaller relative epidemic sizes in rural areas, where connectivity is generally lower. We also computed the strength of correlation between the epidemic sizes of baseline scenarios (uncontrolled outbreaks) and the respective regional gravity index.

In order to explore variation in the relative epidemic size and efficacy of different control strategies for different scenarios, we used generalised linear models (GLMs) and boosted regression trees (BRT) as implemented in the R package dismo [17]. We express results in 
medRxiv preprint doi: https://doi.org/10.1101/2020.09.07.20189597; this version posted September 10, 2020. The copyright holder for this preprint (which was not certified by peer review) is the author/funder, who has granted medRxiv a license to display the preprint in It is made available under a CC-BY-NC-ND 4.0 International license .

COVID-19 disease landscapes

300

301

302

303

304

305

306

307

308

309

310

311

312

313

314

315

316

317

terms of direction of effects (i.e. decrease/increase in relative epidemic size, reflecting

higher/lower control efficacy) and relative influence (i.e. \% of variance explained by various parameters in the corresponding BRT model) for those parameters that appear to show 'significant' effects in both GLM and BRT (i.e. GLM coefficients clearly distinct from zero, relative parameter influence $>5 \%$ ).

All analyses and plotting were conducted in R version 4.0 [18].

\section{Results}

The urban-rural gradient in epidemic sizes (expressed as rank correlation coefficient between the regional epidemic size and the regional gravity index) considerably decreased among baseline scenarios (uncontrolled outbreaks) with larger transmission parameters ( $\beta$, explaining $57 \%$ of changes in total epidemic sizes). This indicates that larger outbreaks in urban areas occur mostly at low transmission parameters. In addition, the urban-rural gradient in total epidemic sizes decreased with higher commuter travel frequency ( $\rho, 19 \%$ of changes in total epidemic sizes) and stronger distance weighting in the underlying gravity model ( $\zeta$, $15 \%$ of changes in total epidemic sizes). This suggests that these factors not only facilitate spatial disease spread but also determine whether outbreaks are larger in urban than in rural environments.

\section{Efficacy of different control strategies in changing disease landscapes}

$\underline{\text { Trace and isolation of all infected individuals (trace all) was by far the most efficient control }}$ strategy in our simulations (Fig 1): no simulated scenario with $\geq 47 \%$ of infected individuals removed $(\kappa)$ had a relative epidemic size $>5 \%$ of the respective baseline scenario. Lowering the epidemic size through isolation of infected individuals was less efficient for large 
medRxiv preprint doi: https://doi.org/10.1101/2020.09.07.20189597; this version posted September 10, 2020. The copyright holder for this preprint (which was not certified by peer review) is the author/funder, who has granted medRxiv a license to display the preprint in COVID-19 disease landscapes

325

transmission parameters ( $\beta$, explaining $19 \%$ relative influence on changes in relative epidemic sizes, Fig 2).

Trace and isolation of symptomatic individuals (trace symptomatic only 2 was of limited efficacy in lowering epidemic size in our simulations. The efficacy of these control strategies largely depends on small transmission parameters $(\beta, 72 \%$ relative influence), whereas variation in the proportion of symptomatic individuals being isolated ( $($ ) explained only $12 \%$ in relative epidemic sizes. The efficacy of this control strategy was further hampered by increasing proportions of asymptomatic cases ( $\varphi, 9 \%$ relative influence).

Regional lockdown scenarios appeared to be of limited efficacy in our simulations (Fig 1) and largely depend on small transmission parameters ( $\beta, 70 \%$ relative influence) (Fig 2 ). Their efficacy was sensitive to the regional threshold levels for lockdown implementation ( $\alpha$, $10 \%$ relative influence) and lockdown stringency ( $\phi, 6 \%$ relative influence). A reduction of relative epidemic sizes to $5 \%$ of those of the respective baseline scenarios through regional lockdowns was only achieved for regional lockdown threshold levels of $\leq 1 \%$ the populations being symptomatic.

\section{Variation in control efficacy across urban-rural gradients}

The strength of the urban-rural gradient in relative epidemic sizes resulting from isolation of all infected individuals (E,A,I) declined with increasing proportions of infected individuals isolated ( $\kappa, 46 \%$ relative influence, Fig 3) and increased with increasing transmission parameters ( $\beta, 24 \%$ relative influence), suggesting that larger transmission rates makes it relatively more challenging to control the spread in urban than in rural areas. In contrast, the more individuals are isolated (increasing $\kappa$ ), the more efficiently can epidemics be also 
medRxiv preprint doi: https://doi.org/10.1101/2020.09.07.20189597; this version posted September 10, 2020. The copyright holder for this preprint (which was not certified by peer review) is the author/funder, who has granted medRxiv a license to display the preprint in COVID-19 disease landscapes

contained in urban environments (i.e. resulting in less strong urban-rural gradients in relative epidemic size), despite a concentration of cases there, as depicted by mostly positive correlation coefficients of the urban-rural gradient in relative epidemic size (Fig 4).

The completely opposite effect was found for the isolation of symptomatic individuals only (I). The strength of the urban-rural gradient in relative epidemic size declined with increasing transmission parameters $(\beta, 52 \%$ relative influence) but increased with increasing proportions of symptomatic individuals isolated ( $\varepsilon, 12 \%$ relative influence). Hence, larger transmission rates make reduction in epidemic size by isolation of symptomatic individuals only more challenging in rural rather than in urban areas. The urban-rural gradient in relative epidemic size further decreased with larger proportions of asymptomatic cases $(\varphi, 11 \%$ relative influence), decreased with higher commuter travel frequency ( $\rho, 8 \%$ relative influence) and increased with stronger density dependence in contact numbers $(\delta, 7 \%$ relative influence, Fig 3).

In response to regional lockdown strategies, the strength of the urban-rural gradient in relative epidemic size increased with increasing transmission parameters $(\beta, 34 \%$ relative influence), increasing travel frequencies (27\% relative influence), and stronger distance weighting in the underlying gravity model ( $\zeta, 18 \%$ relative influence, Fig 3 ).

\section{Discussion}

Decision-making to balance efficient COVID19 control with socio-economic pressures is a challenging task against the backdrop of asymptomatic disease spread and ever-changing disease landscapes. We show that isolation of symptomatic cases, or regional lockdowns in response to local outbreaks, have limited efficacy in terms of reducing overall epidemic sizes, 
medRxiv preprint doi: https://doi.org/10.1101/2020.09.07.20189597; this version posted September 10, 2020. The copyright holder for this preprint (which was not certified by peer review) is the author/funder, who has granted medRxiv a license to display the preprint in COVID-19 disease landscapes

unless overall transmission rate is kept persistently low. Isolation of non-symptomatic infected individuals, which may be detected by effective test and trace approaches, is pivotal to reduce overall epidemic size over a wider range of transmission scenarios. By considering an 'urban-rural epidemic gradient' as the strength of correlation between regional epidemic size and connectivity within a region, we show that under certain conditions, control measures are of limited efficacy in urban compared to rural areas. Intervention strategies focusing on the isolation of non-symptomatic individuals and regional lockdowns, for example, had the strongest urban-rural outbreak gradients at high transmission rates. In contrast, interventions targeting symptomatic virus carrier only had the reverse effect.

Our results emphasise the importance of efficient detection of infectious individuals through test and trace approaches for containing the spread of COVID-19 [2, 19, 20], while also uncovering that some methods will be less efficient in urban areas under the post-lockdown situation unless transmission rates are kept constantly low.

Efficient removal of all infectious individuals (including non-symptomatics) has the potential to restrain total epidemic size by successfully suppressing landscape-scale disease spread and the corresponding source-sink dynamics of how the disease may spread and re-emerge among populations. We found regional lockdowns to be only effective in terms of reducing overall epidemic size if implemented at low threshold levels and low transmission rates. This is likely due to the fact that only under these conditions can landscape-scale spread of the disease be avoided. These findings are in line with previous suggestions that temporary lockdowns do not necessarily contain overall epidemic size in a metapopulation context over medium to long time periods [21], even if they may be useful for reducing local case number over short time periods to avoid an overload of health capacities [22-24]. 
medRxiv preprint doi: https://doi.org/10.1101/2020.09.07.20189597; this version posted September $10,2020$. The copyright holder for this preprint (which was not certified by peer review) is the author/funder, who has granted medRxiv a license to display the preprint in It is made available under a CC-BY-NC-ND 4.0 International license .

COVID-19 disease landscapes

In practice, the prominent example of the locally restricted lockdown implemented in the city that regional lockdowns do not necessarily see an reduction in disease transmission during the following weeks [25], which would ideally prevent spread of the virus beyond the local context. This slow response of incidence decline following regional lockdowns is in line with our finding and more general suggestions that disease with asymptomatic transmission pathways can only be controlled with intensive test and trace approaches [26].

Surprisingly, we found travel frequency and possible density dependence in contact frequency to have rather small relative impact on overall epidemic size compared to the transmission parameter (Fig 2). Despite the recognised importance of connectivity, travel patterns and metapopulation structure on disease spread [27-29] our results highlight the importance of overall transmission rates on disease spread and epidemic size. This has important management implications, as it points to measures that might allow for continuous long-term lowering of transmission rates. Such measures, we suggest, are considerably more efficient than any short-term measures of changing control stringency in response to actual case numbers for reducing the overall epidemic size.

We found the magnitude of transmission rate to also determine the success of different control strategies in urban versus rural areas, leading to varying urban-rural epidemic gradients in response to varying transmission rates and different control strategies (Fig 3). For interventions focused on isolating both non-symptomatic and symptomatic individuals and regional lockdowns, our results reveal the strongest urban-rural epidemic gradients at high transmission rates, indicating a reduced efficacy of such control measure in urban areas 
medRxiv preprint doi: https://doi.org/10.1101/2020.09.07.20189597; this version posted September $10,2020$. The copyright holder for this preprint (which was not certified by peer review) is the author/funder, who has granted medRxiv a license to display the preprint in COVID-19 disease landscapes

under these conditions. These results suggest that at high transmission rates, the urban-rural epidemic gradient is enforced by the overall poorly curbed disease spread at metapopulation level (see Fig 4). Conversely, we found the urban-rural gradient in epidemic sizes to be mostly masked at high transmission rates for measures targeted at symptomatics only, suggesting that that these measures (which are generally of moderate to low efficacy), would not contain disease spread at metapopulation level unless transmission rates are kept constantly low (see Fig 4). Exploring such effects warrants further investigation based on empirical data and relevant spatiotemporal models of disease spread under variable conditions of contact frequencies and control efforts. Such more detailed research may also account for first insights into variable compliance in response to intervention strategies. A recent study, for example, found slightly larger reductions in average mobility in high density than low density areas in the UK [30].

In contrast to many forensic COVID-19 models that have focused on forecasting real outbreaks in specific locations $[1,9,10]$ our model is strategic, with a focus on exploring general mechanisms emerging from across a large range of modelled scenarios. A direct match to the ongoing epidemic in the study area is unfeasible because we do not account for any particular real-world starting conditions nor the temporary changes in human interactions in response to changing policy. Also, as we are not aware of detailed estimates of relevant epidemiological parameters such as how transmission rate varies among age groups in our study area, we do not account for age structure in our model, even though, as it has been shown, COVID-19 effects and expression of symptoms are rather different between children and adults [31]. These effects might be exacerbated by a potential systematic variation in demographic community composition in urban and rural areas. However, with an area-wide spread of COVID-19 in our study area and a concentration of cases in urban communities 
medRxiv preprint doi: https://doi.org/10.1101/2020.09.07.20189597; this version posted September 10, 2020. The copyright holder for this preprint (which was not certified by peer review) is the author/funder, who has granted medRxiv a license to display the preprint in It is made available under a CC-BY-NC-ND 4.0 International license .

COVID-19 disease landscapes

during the first six months of the epidemic, some general patterns found in model output and empirical data appear to be compatible (personal observations). Given more detailed data of spatiotemporal disease spread and better estimates of epidemiological key parameters, future studies may narrow down the currently intractable large parameter space through statistical approximation methods in order to identify when and how management efforts may results in disease extirpation versus long-term persistence [32].

The most important implication from our model is that priority should be given to any reliable and feasible measures that constantly keep transmission rate low as opposed to relying on local lockdowns to stamp out outbreaks. The success of any short-period interventions is limited if overall transmission rate remain high and facilitate disease spread within and among populations. We conclude that in the absence of an intervention strategy that would ensure rapid eradication of COVID-19, different intervention strategies do not work as efficiently in urban as in rural communities. Priority should thus be given to further research on how the most vulnerable individuals can be best protected at minimal cost for entire metapopulations. While post-lockdown situations of low transmission rates and reduced cases number are tempting to ease interventions, we believe that ongoing source-sink dynamics of disease spread cannot be ignored. Successful regional disease control during a pandemic should not ignore the fact that those communities that successfully escaped the first epidemic waves remain the most vulnerable because of large pools of individuals yet to be exposed to COVID-19.

\section{Data accessibility}

473 The R code for this study can be found on GitHub https://github.com/konswells1/COVID19- 
medRxiv preprint doi: https://doi.org/10.1101/2020.09.07.20189597; this version posted September 10, 2020. The copyright holder for this preprint (which was not certified by peer review) is the author/funder, who has granted medRxiv a license to display the preprint in It is made available under a CC-BY-NC-ND 4.0 International license .

COVID-19 disease landscapes

\section{Acknowledgments}

477 We acknowledge the support of funding from the Welsh Government for this project, and

478 also the Supercomputing Wales project, which is part-funded by the European Regional

479 Development Fund (ERDF) via the Welsh Government.

480

481

\section{Author contributions}

$482 \mathrm{KW}$ - Conceptualization, Formal analysis, Writing - original draft, Writing - review \& editing

ML - Conceptualization, Formal analysis, Writing - review \& editing

BC - Formal analysis, Writing - review \& editing

BL - Formal analysis, Writing - review \& editing

RRK - Formal analysis, Writing - review \& editing

ALL - Formal analysis, Writing - review \& editing

SDWF - Formal analysis, Writing - review \& editing

\section{References}

1. Davies NG, Kucharski AJ, Eggo RM, Gimma A, Edmunds WJ, Jombart T, et al. Effects of non-pharmaceutical interventions on COVID-19 cases, deaths, and demand for hospital 
medRxiv preprint doi: https://doi.org/10.1101/2020.09.07.20189597; this version posted September 10, 2020. The copyright holder for this preprint (which was not certified by peer review) is the author/funder, who has granted medRxiv a license to display the preprint in COVID-19 disease landscapes It is made available under a CC-BY-NC-ND 4.0 International license

500

501

502

503

504

505

506

507

508

509

510

511

512

2. Hellewell J, Abbott S, Gimma A, Bosse NI, Jarvis CI, Russell TW, et al. Feasibility of controlling COVID-19 outbreaks by isolation of cases and contacts. The Lancet Global Health. 2020;8(4):e488-e96. doi: 10.1016/S2214-109X(20)30074-7.

3. May RM. Network structure and the biology of populations. Trends in Ecology and Evolution. 2006;21(7):394-9.

4. Rivera MT, Soderstrom SB, Uzzi B. Dynamics of Dyads in Social Networks: Assortative, Relational, and Proximity Mechanisms. Annual Review of Sociology. 2010;36(1):91-115. doi: 10.1146/annurev.soc.34.040507.134743.

5. Block P, Hoffman M, Raabe IJ, Dowd JB, Rahal C, Kashyap R, et al. Social networkbased distancing strategies to flatten the COVID-19 curve in a post-lockdown world. Nature Human Behaviour. 2020;4(6):588-96. doi: 10.1038/s41562-020-0898-6.

6. Gomes MGM, Corder RM, King JG, Langwig KE, Souto-Maior C, Carneiro J, et al. Individual variation in susceptibility or exposure to SARS-CoV-2 lowers the herd immunity threshold. medRxiv. 2020:2020.04.27.20081893. doi: 10.1101/2020.04.27.20081893.

7. Britton T, Ball F, Trapman P. A mathematical model reveals the influence of population heterogeneity on herd immunity to SARS-CoV-2. Science. 2020;369(6505):846-9. doi: 10.1126/science.abc6810.

8. O'Sullivan D, Gahegan M, Exeter DJ, Adams B. Spatially explicit models for exploring COVID-19 lockdown strategies. Transactions in GIS. 2020;24(4):967-1000. doi: 10.1111/tgis. 12660 .

9. Abbott S, Hellewell J, Thompson R, Sherratt K, Gibbs H, Bosse N, et al. Estimating the time-varying reproduction number of SARS-CoV-2 using national and subnational case counts [version 1; peer review: awaiting peer review]. Wellcome Open Research. 2020;5(112). doi: 10.12688/wellcomeopenres.16006.1. 
medRxiv preprint doi: https://doi.org/10.1101/2020.09.07.20189597; this version posted September 10, 2020. The copyright holder for this preprint (which was not certified by peer review) is the author/funder, who has granted medRxiv a license to display the preprint in COVID-19 disease landscapes It is made available under a CC-BY-NC-ND 4.0 International license

525 10. Danon L, Brooks-Pollock E, Bailey M, Keeling MJ. A spatial model of CoVID-19

526 transmission in England and Wales: early spread and peak timing. medRxiv.

527 2020:2020.02.12.20022566. doi: 10.1101/2020.02.12.20022566.

528

11. Tizzoni M, Bajardi P, Decuyper A, Kon Kam King G, Schneider CM, Blondel V, et al. On the use of human mobility proxies for modeling epidemics. PLoS Comp Biol. 2014;10(7):e1003716. doi: 10.1371/journal.pcbi.1003716.

12. Dudas G, Carvalho LM, Bedford T, Tatem AJ, Baele G, Faria NR, et al. Virus genomes reveal factors that spread and sustained the Ebola epidemic. Nature. 2017;544:309. doi: 10.1038/nature22040.

13. Danon L, Read JM, House TA, Vernon MC, Keeling MJ. Social encounter networks: characterizing Great Britain. Proceedings of the Royal Society B: Biological Sciences. 2013;280(1765). doi: 10.1098/rspb.2013.1037.

14. Bailey M, Farrell P, Kuchler T, Stroebel J. Social connectedness in urban areas. Journal of Urban Economics. 2020;118:103264. doi: https://doi.org/10.1016/j.jue.2020.103264.

15. Conlan AJK, Rohani P, Lloyd AL, Keeling M, Grenfell BT. Resolving the impact of waiting time distributions on the persistence of measles. Journal of the Royal Society Interface. 2010;7(45):623-40.

16. Stein M. Large sample properties of simulations using latin hypercube sampling. Technometrics. 1981;29:143-51.

17. Elith J, Leathwick JR, Hastie T. A working guide to boosted regression trees. J Anim Ecol. 2008;77(4):802-13. doi: 10.1111/j.1365-2656.2008.01390.x.

18. R Development Core Team. R: A language and environment for statistical computing. 
medRxiv preprint doi: https://doi.org/10.1101/2020.09.07.20189597; this version posted September 10, 2020. The copyright holder for this preprint (which was not certified by peer review) is the author/funder, who has granted medRxiv a license to display the preprint in

COVID-19 disease landscapes

It is made available under a CC-BY-NC-ND 4.0 International license.

548 19. Ferretti L, Wymant C, Kendall M, Zhao L, Nurtay A, Abeler-Dörner L, et al. Quantifying

549 SARS-CoV-2 transmission suggests epidemic control with digital contact tracing. Science.

$550 \quad$ 2020:eabb6936. doi: 10.1126/science.abb6936.

551

20. Giordano G, Blanchini F, Bruno R, Colaneri P, Di Filippo A, Di Matteo A, et al.

552

Modelling the COVID-19 epidemic and implementation of population-wide interventions

553 in Italy. Nat Med. 2020. doi: 10.1038/s41591-020-0883-7.

554

21. Wells K, Lurgi M. COVID-19 containment policies through time may cost more lives at metapopulation level. medRxiv. 2020. doi: 10.1101/2020.04.22.20075093.

22. Jarvis CI, Van Zandvoort K, Gimma A, Prem K, Auzenbergs M, O’Reilly K, et al. Quantifying the impact of physical distance measures on the transmission of COVID-19 in the UK. BMC Medicine. 2020;18(1):124. doi: 10.1186/s12916-020-01597-8.

23. Ferguson NM, Laydon D, Nedjati-Gilani G, al. e. Report 9: Impact of nondemand. Imperial-College-COVID19-NPI-modelling, 2020 Contract No.: Report 9: impact of non-pharmaceutical interventions (NPIs) to reduce COVID-19 mortality and healthcare demand. March 16, 2020. https://www.imperial.ac.uk/media/imperialcollege/medicine/sph/ide/gidafellowships/

24. Kissler SM, Tedijanto C, Goldstein E, Grad YH, Lipsitch M. Projecting the transmission dynamics of SARS-CoV-2 through the postpandemic period. Science. 2020:eabb5793. doi: 10.1126/science.abb5793.

25. Nazareth J, Minhas JS, Jenkins DR, Sahota A, Khunti K, Haldar P, et al. Early lessons from a second COVID-19 lockdown in Leicester, UK. The Lancet. 2020;396(10245):e4e5. doi: 10.1016/S0140-6736(20)31490-2.

26. Fraser C, Riley S, Anderson RM, Ferguson NM. Factors that make an infectious disease outbreak controllable. Proceedings of the National Academy of Sciences of the United 
medRxiv preprint doi: https://doi.org/10.1101/2020.09.07.20189597; this version posted September 10, 2020. The copyright holder for this preprint (which was not certified by peer review) is the author/funder, who has granted medRxiv a license to display the preprint in It is made available under a CC-BY-NC-ND 4.0 International license .

COVID-19 disease landscapes

573

574

575

576

577

578

579

580

581

582

583

584

585

586

587

588

589

590

591

592

593

594

595

596

597

States of America. 2004;101(16):6146-51. doi: 10.1073/pnas.0307506101. PubMed PMID: WOS:000220978000084.

27. Danon L, House T, Keeling MJ. The role of routine versus random movements on the spread of disease in Great Britain. Epidemics. 2009;1(4):250-8. doi:10.1016/j.epidem.2009.11.002.

28. Heesterbeek H, Anderson RM, Andreasen V, Bansal S, De Angelis D, Dye C, et al. Modeling infectious disease dynamics in the complex landscape of global health. Science. 2015;347(6227). doi: 10.1126/science.aaa4339.

29. Keeling MJ, Gilligan CA. Metapopulation dynamics of bubonic plague. Nature. 2000;407(6806):903-6. doi: doi:10.1038/35038073.

30. Jeffrey B, Walters CE, Ainslie KEC, Eales* O, Ciavarella C, Bhatia S, et al. Report 24: Anonymised and aggregated crowd level mobility data from mobile phones suggests that initial compliance with COVID-19 social distancing interventions was high and geographically consistent across the UK. Lomdon: Imperial College COVID-19 response team, 2020.

31. Davies NG, Klepac P, Liu Y, Prem K, Jit M, Pearson CAB, et al. Age-dependent effects in the transmission and control of COVID-19 epidemics. Nat Med. 2020. doi: $10.1038 / \mathrm{s} 41591-020-0962-9$.

32. Wells K, Hamede RK, Jones ME, Hohenlohe PA, Storfer A, McCallum HI. Individual and temporal variation in pathogen load predicts long-term impacts of an emerging infectious disease. Ecology. 2019;100(3):e02613. doi: 10.1002/ecy.2613. 
medRxiv preprint doi: https://doi.org/10.1101/2020.09.07.20189597; this version posted September 10, 2020. The copyright holder for this preprint (which was not certified by peer review) is the author/funder, who has granted medRxiv a license to display the preprint in It is made available under a CC-BY-NC-ND 4.0 International license

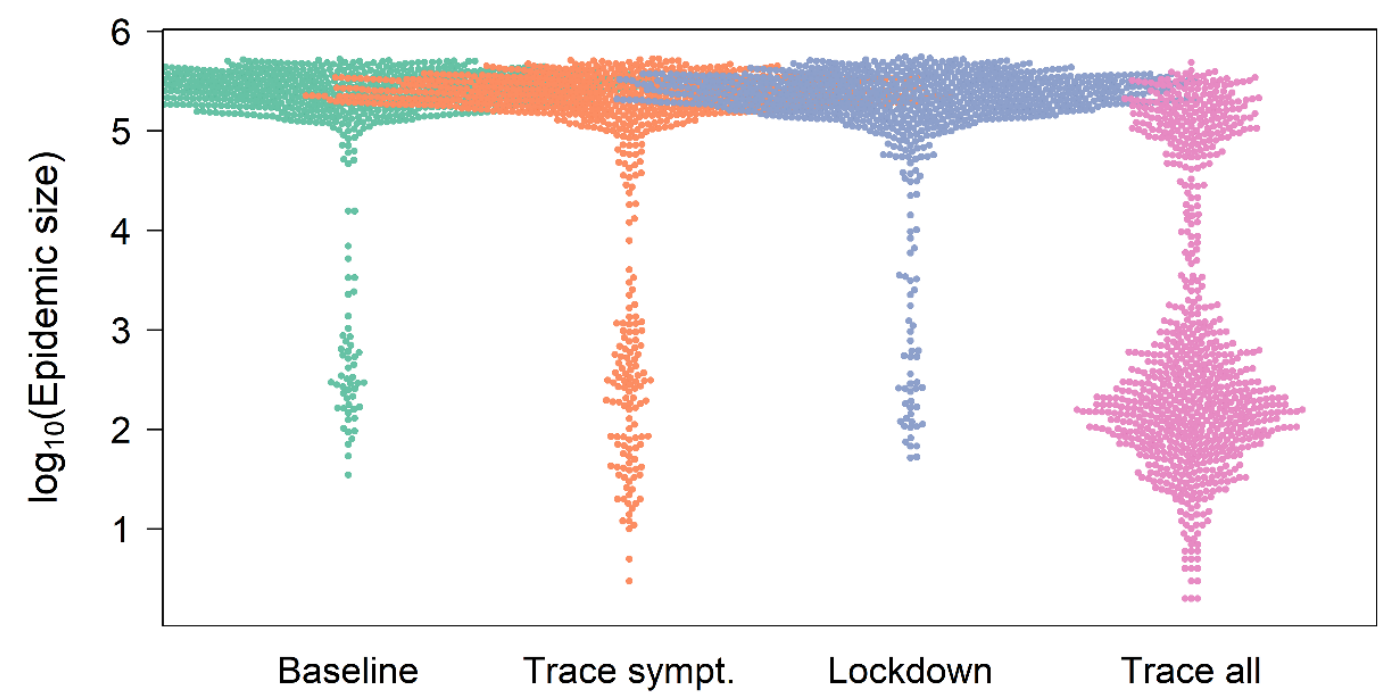

598

Fig 1. Distribution of the total COVID-19 epidemic sizes across an urban-

rural gradient. Plot shows $\log _{10}$-scale epidemic size at metapopulation level

resulting from simulating a large range of scenarios. Scenarios include:

'Baseline': no control strategy; 'Trace sympt.': isolation of a certain percentage

of infectious/symptomatic virus carrier only; 'Lockdown': regional reduction of 
medRxiv preprint doi: https://doi.org/10.1101/2020.09.07.20189597; this version posted September 10, 2020. The copyright holder for this preprint (which was not certified by peer review) is the author/funder, who has granted medRxiv a license to display the preprint in It is made available under a CC-BY-NC-ND 4.0 International license.

COVID-19 disease landscapes

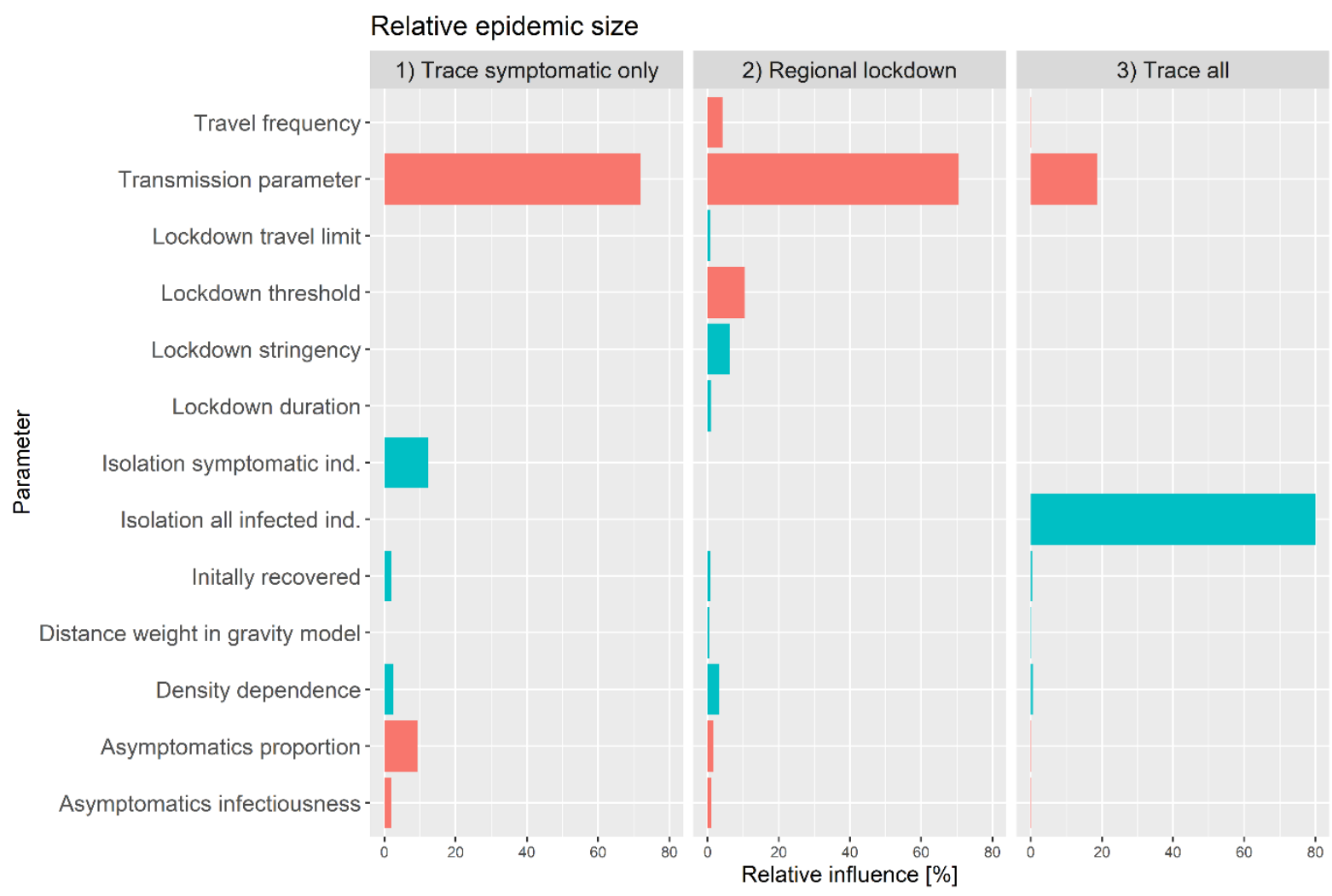

613 Fig 2. Relative influence of different parameters on the relative epidemic

614 sizes. Relative epidemic sizes were calculated for simulations with three

615 different control strategies compared to baseline scenarios of no COVID-19

616 control. The three different control strategies were 'Trace symptomatic only':

617 isolation of a certain percentage of infectious/symptomatic virus carrier only;

618 'Regional lockdown': regional reduction of transmission rates in response to a certain number of infectious/symptomatic virus carriers being present; and

620 'Trace all': isolation of a certain percentage of individuals being infected in the

621 disease states exposed, asymptomatic virus carrier or infectious/symptomatic

622 virus carrier. Green bars indicate smaller and red bars larger relative epidemic sizes with increasing parameter values. 
medRxiv preprint doi: https://doi.org/10.1101/2020.09.07.20189597; this version posted September 10, 2020. The copyright holder for this preprint (which was not certified by peer review) is the author/funder, who has granted medRxiv a license to display the preprint in It is made available under a CC-BY-NC-ND 4.0 International license .

COVID-19 disease landscapes

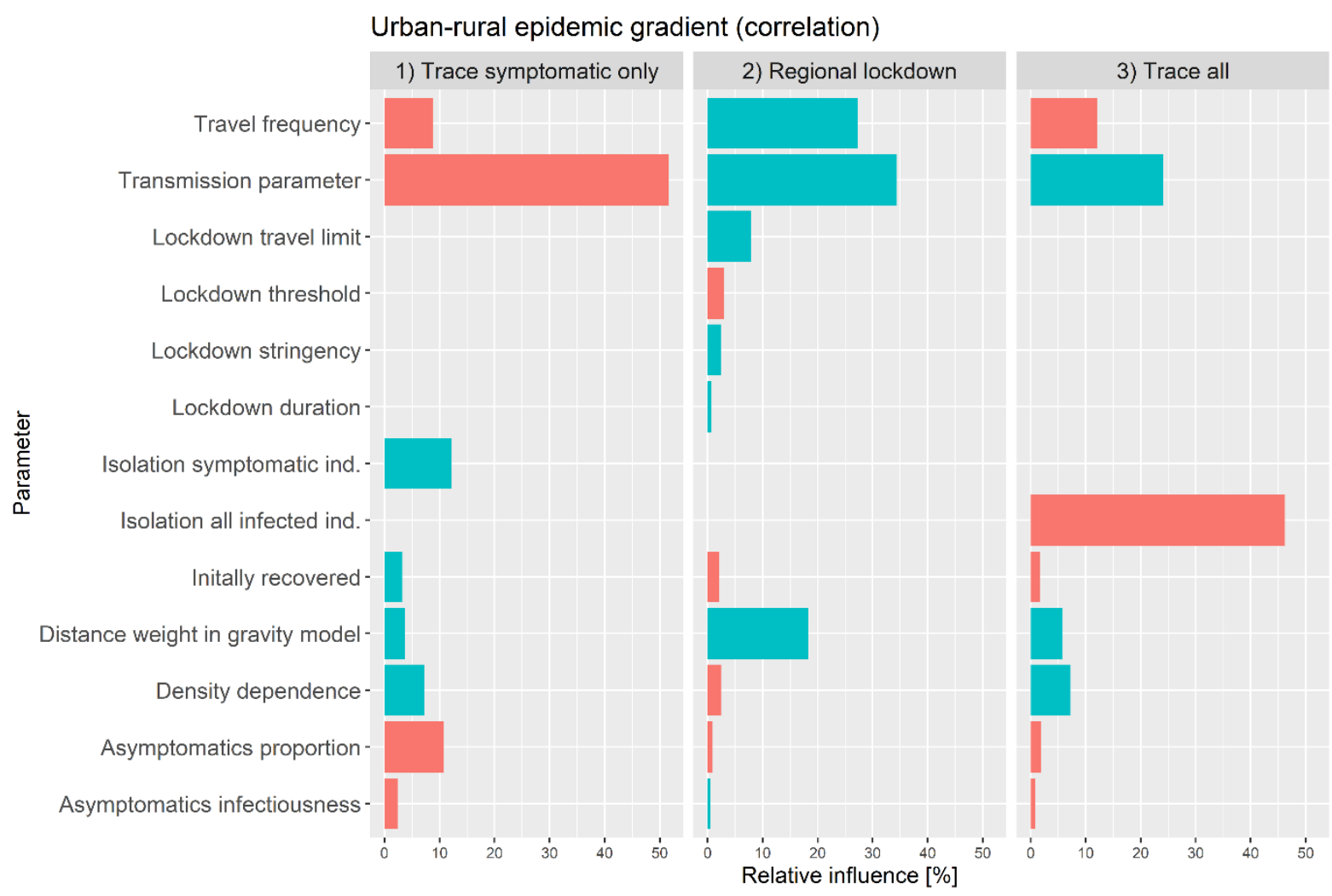

627 Fig 3. Relative influence of different parameters on the 'urban-rural with three different control strategies compared to baseline scenarios of no COVID-19 control. The three different control strategies were 'Trace symptomatic only': isolation of a certain percentage of infectious/symptomatic virus carrier only; 'Regional lockdown': regional reduction of transmission rates in response to a certain number of infectious/symptomatic virus carriers 
medRxiv preprint doi: https://doi.org/10.1101/2020.09.07.20189597; this version posted September $10,2020$. The copyright holder for this preprint (which was not certified by peer review) is the author/funder, who has granted medRxiv a license to display the preprint in It is made available under a CC-BY-NC-ND 4.0 International license .

COVID-19 disease landscapes

637 being present; and 'Trace all': isolation of a certain percentage of individuals

638 being infected in the disease states exposed, asymptomatic virus carrier or

639 infectious/symptomatic virus carrier. Green bars indicate decreases and red

640 bars increases in correlation strength with increasing parameter values.

641

642

643

644

645

646

647

648

649

650

651 
medRxiv preprint doi: https://doi.org/10.1101/2020.09.07.20189597; this version posted September 10, 2020. The copyright holder for this preprint (which was not certified by peer review) is the author/funder, who has granted medRxiv a license to display the preprint in perpetuity.

COVID-19 disease landscapes

652

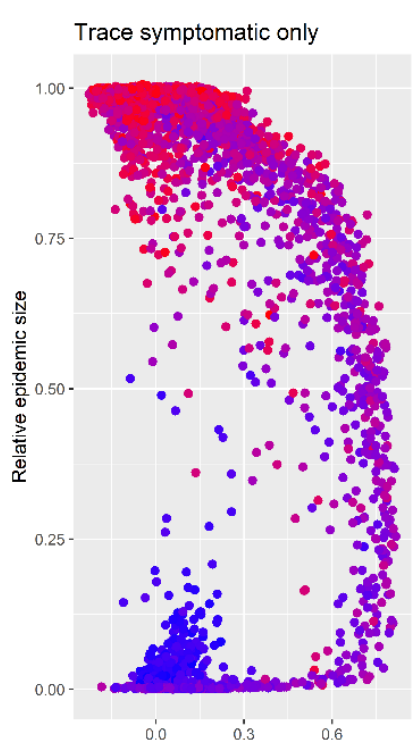

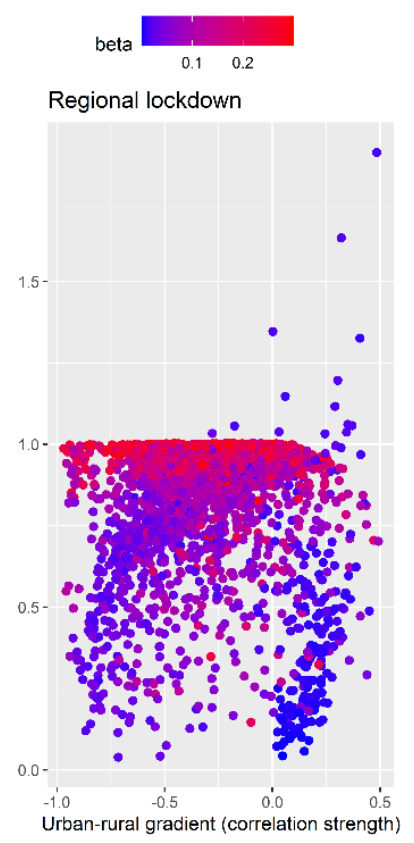

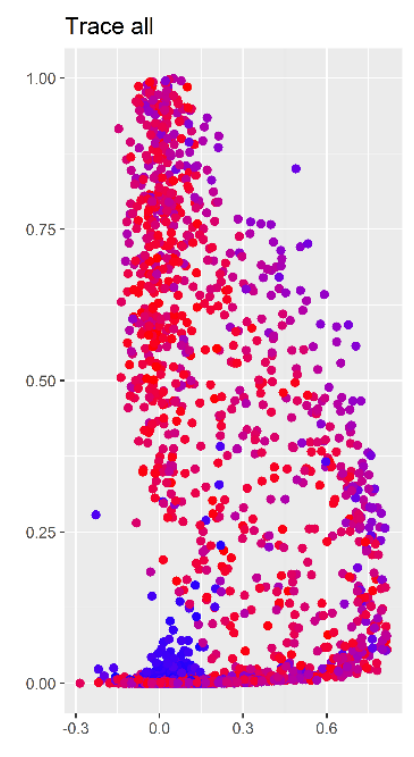

Fig 4. Relationship between overall relative epidemic size for different control measures

epidemic sizes were calculated for simulations with three different control strategies

compared to baseline scenarios of no COVID-19 control. The urban-rural gradient in

epidemic size' was computed as the strength of correlation the regional relative epidemic size and the respective population-level connectivity index. The three different control strategies infectious/symptomatic virus carriers being present; 'Trace all': isolation of a certain percentage of individuals being infected in the disease states exposed, asymptomatic virus carrier or infectious/symptomatic virus carrier. Each point represents the outcome from a simulation with a different baseline scenario, coloured according to the respective value of transmission parameter $(\beta)$. 